Araştırma

Journal of Social Research and Behavioral Sciences

Sosyal Araştırmalar ve Davranış Bilimleri Dergisi

ISSN:2149-178X

Volume: 7 Issue: 13 Year: 2021

\title{
Uluslararası Ziyaretçilerin Gastronomi Davranışları ve Beklentileri: Aydın İli Örneği
}

Emrah Köksal SEZGíN

Aydın Adnan Menderes Üniversitesi

Davutlar Meslek Yüksekokulu

ekoksalsezgin@gmail.com

https://orcid.org/0000-0003-3165-7147

Abdullah TANRISEVDİ

Aydın Adnan Menderes Üniversitesi

Turizm Fakültesi

atanrisevdi@adu.edu.tr

https://orcid.org/0000-0002-6640-2008

$\ddot{\mathbf{O z}}$

$\mathrm{Bu}$ araştırma, gastronomi turizmine dair teorik bilgileri ve uluslararası ziyaretçilerin gastronomi davranışları ve beklentilerini Aydın ili örneğinde belirleme amaçlı bulgu ve yorumları içermektedir. Aydın ilinin gastronomik özelliklerini belirleyerek bu özelliklerin uluslararası gastronomi katılımcılarının tercih ve beklentilerini karşılama düzeylerini ölçmenin amaçlandığg araştırmanın problem cümlesi "Aydın ili gastronomik özellikleri çerçevesinde uluslararası gastronomi katılımcılarının tercih ve beklentilerini karşılama düzeyi nasıldır?” şeklinde belirlenmiştir. Bu genel problem cümlesi ile beraber diğer alt problemlere de cevap aranmıştır. Araştırmanın ilk aşaması, bölgeye gelen turistlerin gastronomi davranışlarını ve tercihlerini belirlemek adına Kuşadası'nda konaklamakta olan turistlere uygulanan anket ile tamamlanmıştır. Çalışmanın ikinci aşamasında, Aydın ili gastronomik özelliklerini belirlemek adına nitel boyutta katılımcılara yarı yapılandırılmış görüşme formu uygulanmıştır. Araştırmanın üçüncü aşamasında ise, belirlenen gastronomik özelliklerin değerlendirmesi adına uluslararası yiyecek festivalleri katılımcılarının Dünya Şefler Birliği’ne ait değerlendirme formu üzerinden Aydın gastronomik özelliklerini yansıtan menüyü değerlendirmeleri istenmiştir.

Anahtar Sözcükler: Uluslararası ziyaretçiler, gastronomi davranışı, gastronomi turizmi, Aydın, Türkiye. 


\title{
International Visitors' Gastronomy Behaviors and Expectations: Aydin Province Model
}

\begin{abstract}
This research includes findings and interpretations aiming to determine theoretical information on gastronomy tourism and international visitors' gastronomy behaviors and expectations in terms of Aydin province model. The problem sentence of the research in which Aydın province's gastronomic properties are aimed to be determined and the fulfillment level of the international visitors' gastronomy behaviors and expectations are aimed to be measured accordingly has been determined as: "what is the fulfillment level of the international visitors' gastronomy preferences and expectations within the scope of Aydin province gastronomic properties?". Along with this general problem sentence, other sub-problems have been tried to be replied as well. The first stage of the research was completed with a questionnaire applied to tourists staying in Kuşadas 1 in order to determine the preferences and expectations of the tourists who visited the region. At the second stage of the research, a semi-structured interview form was applied to the participants in order to determine Aydın province's gastronomic properties from a qualitative point of view. At the third stage of the research, international food festival attendants were requested to make an assessment on the menu which reflects the gastronomic properties of Aydın province through the assessment form of the World Association of Chefs' Societies with the intention of assessment of the determined gastronomic properties of the province.
\end{abstract}

Key Words: International visitors, gastronomy behavior, gastronomy tourism, Aydın, Turkey

\section{Giriş}

Dünyada yeme-içme kültürü bölgelere göre farklılık göstermekte, bir kültür için normal karşılanan yeme içme çeşitliliği, diğer bir toplum tarafından kabul görmeyebilmektedir. Kültürel zenginlik olan bu farklılıkların günümüz turist profilini ortaya çıkarmada önemli payı vardır. Günümüzün turist profili gittiği bölgenin kültürüne uyum sağlamayı seven ve farklı öğeleri tanımak isteyen bir özelliktedir. Bu bağlamda bölgeler, turizm pazarındaki değişime uyum sağlama ve yerel değerleri ön plana çıkartarak rakip bölgelere göre üstün yönlerini göstermeye çalışmaktadırlar. 
Turistler, kültürel değerleri, yerel yemekleri ve farklı tatları tecrübe etmek için gelebilmektedir. $\mathrm{Bu}$ açıdan bölgenin turistik ürünlerinin çeşitlendirilmesi ve yemek-içecek kültürünün turizm faaliyetlerinde ön plana çıkarılmasının cazibeyi artırıcı etkisi olabilmektedir (Yüncü, 2010: 28). Gelişen yiyecek-içecek endüstrisi nedeniyle bu kapsamdaki ihtiyaçların ev dışında karşılanması boş vakitleri değerlendirmeye yönelik bir aktivite olmuştur. Bu aktivite, sadece vakit değerlendirme değil aynı zamanda turizm faaliyeti kapsamında yer aldığı için turist yöresel tatları tecrübe etmek istemektedir (Kastenholz ve Davis, 1999: 355; Gyimothy vd., 2000: 372; Joppe vd.,, 2001: 255). Ülkenin turizm gelirleri ürün çeşitliliği ve pazarlanmasına bağlı olup, sunulan kalite birincil faktör olsa da, uluslararası pazarlama etkinliği de getiriyi artıracaktır (Çetin, 2001: 23). Turistik ürünün çeşitlendirilebilmesi için; talebin beklentileri doğrultusunda kaynağının en iyi şekilde şekillendirilmesi ve sunulması gerekmektedir (Çetin, 2001: 25).

Sağlık, inanç ve diğer turizm çeşitlerine ilişkin aktivitelerin bütün yıla yayılması gerek liliği ancak ürün çeşitlendirmesiyle mümkün olabilecektir. Turizm faaliyetlerinde dönemsellik yerine süreklilik sağlanması arz-talep çeşitliliğini artırarak satış-pazarlama imkânlarını genişletmektedir (Ülker,1998: 86).

Özel ilgi turizmi, birçok farklı özel ilgi kaynaklanan ve öneminin giderek arttığı bir turizm türüdür. Özel ilgi turizmi, kişiyi seyahate iten nedenin özel bir merak veya destinasyona odaklanmasını ifade etmektedir. Bir destinasyonun turist tarafından seçilmesini etkileyen faktörlerden biri, yöresel yeme-içme çeşitleridir. Yerel lezzetleri deneme duygusu, seyahat deneyiminin temel motivasyon faktörü durumundadır (McKercher vd., 2008: 137-138).

$\mathrm{Bu}$ kapsamda, gastronomi turizmi kapsamında turistin restoran ve otellerde kendine yemek hazırlanmasından ziyade, yerel yemek ve içecekleri tatmak içinde seyahat ediyor olduğu ve yerel ürünlerin turizm faaliyetlerine dâhil edilmesinin bölgenin cazibesini arttırıcı etkiye sahip olduğu görülmektedir. $\mathrm{Bu}$ bağlamda, gastronomi turizminin turizm sektörü içindeki payı giderek artmakta, değer kazanmakta ve ülke reklamında önemli bir yer edinmektedir. Akdeniz ülkelerinin turizmde lider olmaları, sahip oldukları kültürel miras ve doğal güzellikleri en iyi şeklide pazarlıyor olmalarından kaynaklanmaktadır. 


\section{Kavramsal Çerçeve}

\subsection{Gastronomi Kavramı}

Yunanca kökenli olan gastronomi, gaster (mide) ve nomas (yasa) sözcüklerinden türeyen, yemek kültürü/yemek sanatı olarak ifade edilebilen, yemeğin kişinin zevkine hitap edecek tarzda, hijyenik hassasiyetleri dikkate alınarak, belli bir düzen içinde sunulması olarak açıklanabilmektedir (Aslan, 2010: 40). Gillespie ve Cousins'e (2001: 2) göre, gastronomi bireysel zevk ile ilgili olup, gastronomik değerler; kültürel, coğrafik, toplumsal ve sosyal beslenme gibi birçok faktöre bağlıdır.

Tüketim ve üretim açısından iki fonksiyonu olan (Akgöl, 2012: 18) gastronominin temel amacını, mümkün olunan en iyi şeklide beslenme ve hayattan zevk alacak besinlerle beslenme şeklinde açıklamak mümkündür. Gastronominin işlevi ise, temel ilkelere dayanarak, yiyecek haline dönüştürülebilecek her şeyi arayan, sağlayan ve hazırlayan herkese rehberlik sağlamaktır (Kemer, 2011: 5).

\subsection{Gastronominin Tarihsel Gelişimi}

İlk dönemlerden günümüze kadar gelen süreçte yeme kültürünün derinleşmesi, felsefi soruların ortaya çıkmasına da zemin hazırlamıştır. Tercihlerin önemli olmadığı eski dönemlerde, insanın hayatta kalmak için beslendiği açıkça görülmektedir (Belge, 2008: 34-35). Ateşin bulunmasından sonra, yabani bitkilerin ehlileştirilmesi, tarımsal faaliyetlerin artması gibi gelişmeler ağırlıklı olarak etle beslenen insanoğlunun beslenme şeklinin, bitki ağırlıklı bir yönelime girmesini sağlamıştır. Bu durum yemek kültürünün değişimini hızlandırmıştır.

Tarihte bilinen ilk yemek tarifleri, yemek konusunda meraklı Latin Apicius'lar (M.Ö.1-M.S.3. yy) tarafından yapılmıştır. Bunun yanında Mezopotamya'da bulunan (M.Ö. 1700) kil tabletlerin üzerinde yemek tariflerinin yazılı olduğu da bilinmektedir. Ayrıca 9. Yüzyıla ait rölyeflerin üzerinde ekmek-yemek pişirme tasvirlerinin bulunması yemek tarifi niteliği taşımaktadır. 
Yemeklerin açık şekilden kaplarda pişirilmesine geçiş süreci MÖ. 6000 yılına kadar sürmüştür. Ticaretin gelişmesiyle beraber, besin maddelerine ticari mal gözüyle bakılmış; bu durum yiyecek malzemelerinin uzak coğrafyalara taşınmasını sağlamıştır (Halıcı, 1982: 44). Yemek pişirme sanatının temellerinin Mezopotamya' da atıldığı bilinmektedir. Süreç içinde Mezopotamya mutfağı Çin ve Anadolu şeklinde ikiye ayrılmıştır. Ayrılan bu iki mutfak zaman içinde gelişmiş ve ÇinJapon mutfağını, Anadolu ise, Mısır mutfağının ortaya çıkmasını sağlamıştır (Ciğerim, 2001: 50).

Ticari hayatta yaşanan gelişmeler ve yaygınlaşma tüccarların konaklayabilecekleri ve yemek yiyebilecekleri mekanların yapılmasını da zorunlu kılmıştır. Orta çağdaki zengin sınıfın yemek kültürüne her hangi bir katkısından söz etmek pek mümkün değildir. Ressamların yemek yeme anlarını resmettikleri tablolar, dönemin yemek yeme şekilleri, yemek sunumları ve sofra düzeni gibi ayrıntılar hakkında bilgi edinilmesini sağlamaktadır (Dilsiz, 2010).

\subsection{Gastronomi Turizmi}

Literatürde yiyecek turizmi, mutfak turizmi gibi kavramlar olarak da bilinen gastronomi turizminin birbirinden farklı anlamlara geldiği görülmektedir. Çoğu zaman birbiri yerine kullanılan bu kavramlar temelde birbirinden ayrilmaktadır (Hall ve Sharples, 2003:11). Turizmi, yiyecek ve içecek sektörü etkilemekte; bu kapsamda destinasyonları ziyaret etme, bilinmeyen lezzetleri deneme ve yeni kültürleri değerlendirme olanağı ortaya çıkmaktadır (Cook vd., 1999:127).

Gastronomi turizmi içinde, gideceği yeri, yörenin özelliklerine ve tatlarına göre özellikle belirleyen turistlerin ayrı bir konumu vardır. Seyahat sırasında herhangi bir restorana ziyaret gastronomi turizmi sayılmazken, özel bir yiyeceği, belli bir yöreye ait bir ürünü, belirli bir aşçının hazırladığı yemeği tatma isteği gastronomi ile ilgili bir ziyareti güdüleyen nedenler arasında olmaktadır (Hall ve Sharples 2003:10).

Gastronomi turizmini, turistlerin konakladıkları mekânların dışında özellikle yöreye ait yiyecek ve içeceklerle ilgili deneyimler yaşamak için turistik faaliyetlere katılmaları şeklinde tanımlamak mümkündür. Yemeğin bir toplumun kendisini ifade etme şekli olduğu düşünüldüğünde; kültürün gastronomi turizminin ayrılmaz bir parçası olduğu söylenebilir. Bu durum, gastronomi turizminin, 
kültürel turizm ile olan ilişkisini açıklamaktadır (Hjalager, Corigliano, 2000: 282). Gastronomi turizmi, yiyecek ve içeceklerin tüketiciyi cezbedici şekilde sunulmasıdır. Sunulan lezzetin övülmesi veya bir eleştirmen tarafından tavsiye edilmesi gerekmemektedir çünkü gastroturist araştırmacı olmalı ve yerel deneyimleri yaşamaktan çekinmemelidir (Wolf, 2006: 2).

Yemek, farklı bir kültürü anlamanın en iyi yollarından birisidir çünkü yabancı bir toplumu duygusal yönüyle de tanımayı sağlamaktadır (Shenoy, 2005: 1). Farklı toplumların yiyeceklerinin tadılması yabancı kültürü özümseme yollarından birisidir (Long 2003: 2). Yiyecek, bir yeri ziyaret etmede toplam ziyaret deneyiminin bir parçası olarak düşünülmektedir. Fakat yiyecek, turistlerin yeni ve otantik deneyimler ve alternatif turizm çeşitlerini istemelerinden dolayı, en önemli ve eğlenceli etkinlik konumundadır (Hjalager ve Richards, 2002: 283).

Gastronomi turizminin günümüzdeki şeklini almasında etkili olan faktörleri Boniface (2003: 14) tarımın ortaya çıkışı, kültürel etkileşimler, küreselleşme, gıda güvenliği olarak açıklamıştır. Özellikle 1990'lı yıllardan itibaren seyahat edenlerin taleplerinde değişmeler başlamıştır. Yöreyi çekici kılan kültür, tarihi miras ve sanat gibi faktörlerin yanında yemeğin de kültürel bir miras olduğu düşünüldüğünde yöreyi çekici kılan faktörlerden birisi olduğu kabul görmüştür. $\mathrm{Bu}$ noktadan hareketle gastronomi turizminin uluslararası turizmde önemli bir katkısının olduğunu söylemek mümkündür (Altınel, 2009:15).

\subsection{Gastro Turist Tanımı ve Profili}

Gastronomi kültürünün yayılması, yüksek gelirli ve eğitimli kişilerin bir bölgeye has yiyecek ve içecekleri deneyimlemek için seyahatlere çıkmaları ile gelişmiş ve gastroturist kavramı ortaya çıkmıştır (Hatipoğlu, 2010: 4). Gastro turist özellikle fiziksel ihtiyacını gidermek için besin tüketimi yapmamakta, farklı besinleri deneyimlemektedir (Long, 2003: 21). Gastro turist; turizm kavramı açısından ele alındığında, bireyin yaşadığı yerden yemek yemek için başka bir yere gidebilecek olan olanaklara sahip kişiler olarak tanımlamak mümkündür.

Toplumlarda bu imkânlara sahip kişiler arasında gastronominin durumu farklılaşmaktadır. Gastronomi ile ilgilenen birey geleneksel lezzetler ve ülkeye özgü yemeklerin sadece biri ile değil; 
bu yemeklerin hepsi ile uygun yer, uygun zaman ve uygun şartlar altında ilgilenmektedir (Hatipoğlu, 2010: 6). Turistin bir bölgede gastronomi ile ilgili bir etkinliğe hangi sebeple katıldığ1 değil, deneyim kazanması gastronomi turizminin bir yönünü oluşturmaktadır. Etkinliğe katılan turist yemekleri tadarak farklı kültürleri tanımada olumlu bir deneyim kazanmaktadır (Silkes, 2007:20).

Gastro turistin seyahat motivasyonları (Akgöl, 2012: 41); ünlü bir lokantanın aşçısının katıldığı bir pişirme performansını seyretmek, ünlü bir lokantada özel bir programa katılmak, sadece yerel halkın gittiği bir lokantaya gitmek, festivallere katılmak, yöresel yiyecekleri araştırmak, üretim sürecini takip etmek, yemek kurslarına katılmak şeklinde ifade edilebilir. Gastronomi turizmi sadece bireysel turistler veya küçük gruplara hitap etmemektedir. Aynı zamanda aşçılar ve konuyla ilgili diğer profesyoneller de öğrenme, eğitim, yarışma amaçlı seyahatleri sırasında gastro turist sayılmaktadırlar.

\subsection{Gastronomi Turizminin Uluslararası Önemi}

Gastronomi turizmi, ürünü bir ülkenin kendi kültürü ile oluşturduğu kavramla sadece kendilerinin kullanabilecekleri bir şekilde ortaya çıkan zenginlikleridir. Ülkenin gastronomi ürünü kendi kültürü ile markalaşmakta ve özgün olmaktadır (Okumuş vd., 2007:253). Bölgenin sahip olduğu gastronomi ürünleri yörenin de tanıtılmasına katkı sağlamaktadır. Yörenin sahip olduğu gastronomi ürünü yörenin tarım ürünlerine katma değer yaratır ve destinasyon pazarlaması yönünde yerel kimliği geliştirir (Dilsiz, 2010).

Gastronomi turizmi, yörenin pazarlanması açısından da önemli bir etkendir. Yörenin mevsimine uygun yerel pazarların kurulması gerekmekte ve sürekli olarak yapılması gereken etkinlikler olarak görülmesi gerekmektedir. Yerel pazarların bünyesinde barındırdığı; sebze, meyve ve hayvansal gıdalar önceleri agro-turistin ilgi alanını oluştururken, zamanla yerel pazarlara daha fazla üreticinin ve yöresel ürünlerin de dahil olması gastroturistin de ilgisini çekmiştir. Üreticinin ürününü doğrudan tüketiciye ulaştırması, bunların; memnuniyet ve yeni müşterilerin kazanılmasını sağlayacaktır. 
Turistin belli bir yöreyi tercih etmesi için yerel halkın ve ziyaretçilerin katılımı ile etkinlikler düzenlenebilir ve geceleme sayısı artırılabilir. Yemek festivalleri, pek çok yatırımcı ve destinasyon pazarlama işletmeleri tarafından ekonomik çözüm gibi sunulmaya çalışılsa da tek başına ekonomik katk1 oluşturamazlar. Yiyeceklerin hazırlanmasına ve bu hazırlı̆ga yönelik eğitimle ilgili gastronomi turizmi ürünleri de yaratılmalıdır. Bundan ziyade yapılacak olan aktiviteler belirli bir tema çerçevesinde gerçekleştirilmelidir. Etkinliklere katılan ünlü aşçıların, yöresel yemeklerin ve nadir bulunan lezzetlerin farklı mekânlarda ortaya çıkması sağlanmalıdır (Wolf, 2006: 30, 37).

İşletmelerin sunduğu hizmetler, yörenin çekiciliğini arttıran bir unsurdur. İşletme müşteriye tatmin edici hizmet sunamıyorsa yörenin de imajını zedelemektedir. Günümüz şartlarında rekabet ortamının gün geçtikçe artması, ekonomik açıdan kazanç sağlamak isteyen yörenin reklamını en iyi şekilde yapmasını gerekli kılmaktadır. Bu bağlamda, müşterinin kalıcılığını sağlamaya yönelik yeni stratejileri de hayata geçirilmesi gerekmektedir. Rekabet ortamında uygulanan her stratejik yenilik işletmelere yarar sağlayabileceği gibi, diğer işletmelerin gerisinde kalınması da işletmeyi olumsuz yönde etkileyebilecektir.

Gastronomi gün geçtikçe ülkelerin kendi tanıtımını-reklamını yaptığı bir şekle dönüşmüştür. Ülkeler gastronomiye sadece bir kültür değeri olarak bakmamakta, ülkenin reklam yüzü olarak da kullanmaktadırlar. $\mathrm{Bu}$ doğrultuda yapılan festivaller ve sempozyumlar aracıllğıyla ürünlerin uluslararası boyutta tanıtılmasını sağlayarak ülkenin adını duyurmaktadırlar (Dilsiz, 2010: 20).

\subsection{Dünyada Gastronomi Turizmi}

Globalleşme sürecinde ülkelerin yemek kültürleri, mutfak düzeni, kullanım alışkanlığı ve tüketim gibi olgularda etkilenmiştir. Lakin kültürel ve yöresel yiyecek-içeceklerin özgünlüğünün korunması gerekmektedir. Ülkenin maddi ve teknolojik gelişmişliği, mutfak ve yemek kültürüne etkisi en az olan iki unsurdur. Çünkü güçlü bir mutfağın oluşması edinilen deneyimler ve bilgi birikimin sonucu olarak ortaya çıkmaktadır.

İnsanların refah seviyesinin yükselmesi, zevk almaya yönelik faaliyetlerin önem kazanmasına zemin hazırlamıştır. Yiyecek-içeceklerin önem kazanmaya başladığı bu dönemde, dünya ülkeleri 
gastronomiye önem vermeye ve ülke yararına kullanmaya yönelmişlerdir. Rekabet halindeki destinasyonlar, başta Fransa, İspanya, İtalya gibi ülkelere yoğunlaşan gastronomi turlarını kendi ülkelerine de çekme gayreti içine girmişlerdir. Bu bağlamda, Avrupa ülkeleri mutfak kavramı ile ön plana çıkmakta ve ülkelerinin tanıtımını yapmaktadırlar. Gastronomi alanında öne çıkmış olan; İspanya, Fransa, İtalya gibi ülkelerin pazardaki payı fazladır.

Ülkelerin kendi mutfaklarını ön plana çıkarmaya çalışarak gastronomi turizminden olabildiğince fazla yararlanmak istemeleri, mutfaklarını yenilemeleri ve gastronomi turizmine yatırım yapmalarını gerekli kılmıştır. İnsanlar uluslararası ulaşımın kolaylaşması ve gelişmesiyle beraber bilgi sahibi oldukları kültürleri tanıma ve ifade şekillerini tatmak istemektedir (Hacığlu, vd., 2009). Yöresel yiyeceklerin yapılış tekniği, yiyecek maddesi, pişirme malzemesi, geleneksel kıyafetleri gastro turistin ilgisini çekmektedir. Zira her ülkenin hatta her yörenin gelenekleri farklılık göstermekte ve bu gelenekler nesilden nesle aktarılarak olgunlaşmaktadır (Küçükaltan, 2009).

Özel ilgi turları olarak gerçekleştirilen gastronomik seyahatler, özellikle gazete ve dergilerin yemek yazarları, araştırmacılar, gurmeler ve gastronomi konusunda seçilmiş kurum ve kuruluşlar tarafından tercih edilmektedir. Düzenlenen dünya turlan kapsamına; önemli gastronomi merkezlerindeki aşçılık okullarına, yerel mutfakları ile ünlü gastronomi merkezlerine, gıda pazarlarına/fuarlarına, kahve, çay, ekim ve hasat turlarına, çikolata ve şarap turları gibi seçenekleri de ekleyerek müşterilerinin destinasyon tercihlerine sunulmaktadır (Shenoy, 2005).

\subsection{Türkiye'de Gastronomi Turizmi}

Türkiye'nin sahip olduğu yedi coğrafi bölgenin her birinin farklı kültürlere ev sahipliği yapması ve bu duruma paralel olarak yemek çeşitliliğinin fazla olmasına rağmen, bireylerin Fastfood ürünlerine rağbet etmesi, Türk yemek kültürünün tanınmasını engellemektedir. Köklü bir yemek kültürüne sahip Türkiye, her bölgede oluşmuş coğrafi çeşitlilik avantajı sebebiyle, bölgesel farklı lezzetleri de içerisinde barındırma özelliği kazanmıştır. Ayrıca, yemek kültüründeki çeşitliliğinin 
fazla olmasına rağmen gastro turların tur paketlerine dâhil edilmemesi ülkenin uluslararası ve ulusal düzeydeki gastronomi etkinliğini azaltmaktadır.

Türkiye'nin doğa, tarih, gastronomi ve diğer turizm çeşitlerinde potansiyelinin yüksek olması ürün çeşitlendirilmesi ve süreklilik bakımından büyük bir avantaj sağlamaktadır. Türkiye'nin gurmeleri çekme potansiyelini yeterince pazarlayamadığ görülmektedir. Bunun temel nedeni, turizmin sadece doğal ve tarihi güzellikler olduğu algısının yerleşmiş olması ve gastronomiye hak ettiği önemin verilmemesidir (Kemer, 2011: 5).

Türkiye'nin de içinde bulunduğu Akdeniz ülkelerinde yiyecek kültürü ağırlıklı olarak yeşil bitkilerden oluşmakta, soğuk iklimin hâkim olduğu bölgelerde ise tatlı ağırlıklı beslenme şekli görülmektedir. Bu durum yaşanılan bölgenin yemek kültürüne doğrudan etki ettiğinin kanıtıdır (Dilsiz, 2010: 19). Türkiye, orta kuşakta yer alan ve yılda dört mevsimi yaşayan, doğal güzellikleri, tarihi ve kültürel mirasıyla turistlerin çekim alanı konumundadır. Türkiye'de yedi bölgeye ayrılmış topraklar üzerinde birbirinden lezzetli, her bölgenin kendisine has yemek çeşitliliği oluşmuştur. $\mathrm{Bu}$ bağlamda, turizmde önemli bir tanıtım aracı olan "gastronominin" değeri her bölgede vurgulanarak, var olan bölgesel lezzetler o yörenin çekim gücünü artıracak projelerle tanıtılmalıdır (Dilsiz, 2010: 20).

T.C. Kültür ve Turizm Bakanlığı, Türk mutfağına özgün, nitelikli hizmet veren, ulusal veya uluslararası şöhret sahibi, kamuoyu nezdinde markalaşmış ve bu markayı uzun süre sürdüren işletmelere "Özel Tesis Turizm Işsletmesi Belgesi" vermek için çalışmalar yapmaktadır. Bakanlığın verdiği belgeye sahip olmak isteyen işletmelere Bakanlık tefriş, dekorasyon, fiziksel nitelikler, işletme ve hizmet kalitesi konularında yönlendirme yapmayı da planlamaktadır (Aslan, 2010: 44).

\section{Yöntem}

\subsection{Araştırmanın Yöntemi}

Aydın ilinin gastronomik özelliklerini belirleyerek, bu özelliklerin uluslararası gastronomi katılımcıları açısından tercih ve beklentilerini karşılama düzeylerini ölçüldüğü bu çalışmada nitel 
ve nicel olmak üzere karma yöntemden yararlanılmıştır. Bu çerçevede araştırma üç aşamadan oluşmuştur. Araştırmanın ilk aşamasında nicel boyutta gastronomi davranışları ve tercihleri ölçeği örneklemimize uygulanmıştır. Ölçeğin güvenilirliğini test etmek amacı ile ölçek maddelerinin Cronbach Alpha katsayıları hesaplanmıştır. Ölçeğin iç tutarlılık güvenilirlik katsayısı .72 bulunmuştur. Güvenilirlik katsayısı $0.61<\alpha<0,80$ arasında olduğundan, ölçek güvenilirliği kabul edilebilir seviyede olduğu gözlenmiştir. Ölçeğin yapı geçerliliğini test ederek, farklı boyutlarda ayrışıp ayrışmadığını test etmek amacı ile faktör analizi uygulanmıştır. Araştırmamızın ikinci aşamasında, nitel boyutta katılımcılara yarı yapılandırılmış görüşme formu uygulanmıştır. Araştırmamızın üçüncü aşamasında ise katılımcılara Dünya Şefler Birliği (WACS)'ne ait uluslararası yarışmalarda kullanılan 100 puan üzerinden gerçekleştirilen değerlendirme formu uygulanmıştır.

\subsection{Veri Toplama Yöntemi}

Araştırmanın birinci aşaması 15 Şubat 2016 tarihinde Kuşadası Labranda Ephesus Princess Hotel'de genel müdürlükten özel olarak alınan izinle konaklamakta olan turistlere uygulanan anket ile tamamlanmıştır. Anket Hasan Aslan tarafından 2010 yılında Konya ilinde hazırlanmış ve uygulanmış olan "Gastronomi Turizminin Turizm Eğitimi Programlarındaki Yeri ve Önemi-Bir Uygulama" isimli yüksek lisans çalışması baz alınarak hazırlanmıştır. Bu çalışmanın anket formundaki maddeler oluşturulurken Hall ve Mitchell (2005), Şanler (2005), Akman (1998), Shenoy (2005)'in konu ile ilgili yaptı̆̆ 1 araştırmalardan ve ilgili literatürden yararlanıldığ 1 belirtilmektedir. Aslan'ın yapmış olduğu çalışmanın anketinde yer alan "D-Gastronomi Davranışlarını Değerlendirmeye Yönelik Sorular” bölümü demografik seyahat özelliklere göre uyarlanmıştır. Ölçekteki maddelere ilişkin katılma düzeyini ifade etmek için 5'li Likert (Kesinlikle Kat1lmıorum “1”, Kat1lmıyorum “2”, Ne Kat1lıyor Ne Katılmıyorum “3”, Kat1lıyorum "4” ve Kesinlikle Katılıyorum "5") tipi dereceleme ölçeği kullanılmıştır.

Araştırmanın yapı geçerliliğini sağlamak için açıklayıcı faktör analizi uygulanmıştır. Gastronomi Davranışları Değerlendirme Anketi Faktör Analizi sonucunda katılımcıların iki temel gastronomik davranış gösterdiği belirlenmiştir. Bunlar; 
1. Gastronomi Deneyimi I

2. Gastronomi Deneyimi II'dir.

Gastronomi davranışları değerlendirme anketi faktör analizinin ikinci adımında ise faktör analizi sonucunda 3 alt faktörden oluştuğu görülmüştür. Bu faktörler;

1.Faktör: Tercih faktörü (T1, T6, T2, T8, T3, T7)

2.Faktör: Satın Alma Faktörü 1 (T4, T5, T11)

3.Faktör: Satın Alma Faktörü 2 (T9, T10)

olarak isimlendirilmiştir.

Çalışmanın ikinci aşaması olan Aydın ilinin gastronomik potansiyelinin belirlenmesi amacıyla uygulanan yarı yapılandırılmış sorular, uzman görüşü alındıktan sonra tespit edilmiştir. Görüşmelerde çalışmanın amacına uygun olarak hazırlanmış aşağıdaki sorular kullanılmıştır.

1. Sizce buraya gelen turistler ne yemeli ve içmelidir?

2. Önerdiğiniz bu yiyecek ve içeceklerin bir yapım hikâyesi var mı?

3. Önerdiğiniz bu yiyecek ve içeceklerin tarifini verebilir misiniz?

4. Size göre değeri bilinmeyen, unutulmaya yüz tutan gastronomik ürünler var mı?

Araştırmanın üçüncü aşamasında ise belirlenen özelliklerden derlenen Aydın ili menüleri, araştırmacının davet edildiği uluslararası yiyecek festivalleri olan 14-20 Mart 2016 Hoi An Food Festival Vietnam'da 93 kişiye ve 7-10 Nisan 2017 Biser Mora Hirvatistan'da 77 kişiye deneyimletilerek, toplamda 170 uluslararası katılımcı üzerinde gerçekleştirilmiştir. Katılımcıların tercih ve beklenti düzeyleri, Dünya Şefler Birliği (WACS) tarafından uluslararası yarışmalarda kullanılan değerlendirme formu yardımıyla ölçülmüsşür. Söz konusu formdaki sorular EK 2'de sunulmuştur. Forma ek olarak demografik özellikleri belirleyen sorular haricinde aşağıdaki sorular kullanılmıştır:

1. Daha önce Türk Mutfağ denediniz mi?

2. Yemek seçiminde dikkat ettiğiniz özellikler nelerdir?

3. Gastronomi turizmi için Aydın bölgesini tercih eder misiniz? 


\subsection{Verilerin Analizi}

Nitel verilerin analizinde içerik analizinden yararlanılmıştır. Bunun için, anahtar sözcükler, alt kategoriler ve kategoriler oluşturulmuştur.

Nicel verilerin düzenlenmesinde; veriler IBM SPSS 21.0 paket programıla çözümlenmiş, verilerin analizinde maddeler temel alınarak bağımsız örneklem t-testi ve Anova ve açıklayıcı faktör analizi kullanılmıştır. Verilerin analizinden önce normal dağılım varsayımlarının karşılanıp karşılanmadığı kontrol edilmiştir.

\subsection{Normal Dağılım Analizleri}

İstatistiksel testler, "parametrik testler" ve "parametrik olmayan testler" olmak üzere ikiye ayrılmaktadır. Eldeki bir veri setine, bu testlerden hangisinin uygun olduğunu belirlemek için normallik testi yapılmalıdır. Eğer veriler normal dağılıma sahip ise parametrik testler, veriler normal dağılıma sahip değil ise parametrik olmayan testler (non-parametrik testler) uygun olacaktır.

“Gastronomi Davranışları Değerlendirme Anketi” incelendiğinde, verilerin demografik özelliklere göre normal dağıldığ 1 görülmektedir. Tabachnick and Fidell'e (2013) göre verilerin normal dağılım gösterdiğini kabul edebilmemiz için çarpıklık ve basıklık değerlerinin -1.5 ile +1.5 arasında olması gerekmektedir. Aynı şekilde George, D., \& Mallery, M. (2010)'in "SPSS for Windows Step by Step: A Simple Guide and Reference" adlı çalışmaları incelendiğinde, verilerin normal dağılım gösterebilmesi için çarpıklık ve basıklık değerlerinin -2.0 ile +2.0 arasında olması gerektiğini vurgulamaktadırlar. Dolayısıyla analizi yapılan tüm veri setinin söz konusu aralıklarda olduğu görülmekte ve verilerimizin normal dağıldığı gözlenmektedir.

Her bir normallik testinin uygulanabilmesi için kendilerine has bazı ön şartları bulunmaktadır. Bazıları için bu ön şartlar içinde örneklem büyüklüğü de bulunmaktadır. Örneğin Kolmogorov- 
Smirnov kullanılacaksa örneklem büyüklüğünün 50'den fazla olması tavsiye edilmektedir (Kuram Ve Uygulamada Eğitim Bilimleri, 2017). Dolayısıyla örneklem büyüklüğü 50'den fazla olmasından dolayı tüm testlerde Kolmogorov-Smirnova sonucuna bakılmıştır.

\section{Bulgular}

Araştırmamızın problemlerine ilişkin bulgular ve yorumlarımız aşağıda sunulmuştur:

\subsection{Birinci Alt Probleme İlişskin Bulgular}

Araştırmanın birinci alt problemi "Aydın bölgesine gelen uluslararası ziyaretçilerin gastronomi davranışları bölgenin gastronomi turizmi açısından değerlendirilmesine olanak sağlamakta mı?” şeklinde belirlenmiştir.

Çalışmanın bu bölümü 15 Şubat 2016 tarihinde Kuşadası Ephesus Princes Hotel'de konaklamakta olan turistlerden 260'ına yönelik demografik özellikler ve gastronomi davranışlarını ölçer bir anket ile tamamlanmıştır. Uygulanan anketlerden 34 tanesi eksik ve hatalı bilgi içerdiği için değerlendirme dışı bırakılmış, doğru ve eksiksiz cevaplanan 226 anket çalışmaya dâhil edilmiştir. Anket Hasan Aslan tarafindan 2010 yılında Konya ilinde hazırlanmış ve uygulanmış olan "Gastronomi Turizminin Turizm Eğitimi Programlarındaki Yeri ve Önemi-Bir Uygulama" isimli yüksek lisans çalışması baz alınarak hazırlanmıştır. Yine bu çalışmanın anket formundaki maddeler oluşturulurken Hall ve Mitchell (2005), Şanler (2005), Akman (1998), Shenoy (2005)'in konu ile ilgili yaptığ araştırmalardan ve ilgili literatürden yararlanıldığı belirtilmektedir. Aslan'ın yapmış olduğu çalışmanın anketinde yer alan "D-Gastronomi Davranışlarını Değerlendirmeye Yönelik Sorular" bölümü ankete uygulanarak yapılmıştır.

Aydın ilinin gastronomik özelliklerini belirleyerek bu özelliklerin uluslararası gastronomi katılımcılarının tercih ve beklentilerini karşılama düzeylerini ölçmeyi amaçlayan bu araştırmanın problem cümlesi "Aydın ili gastronomik özellikleri çerçevesinde uluslararası gastronomi 
katılımcılarının tercih ve beklentilerini karşılama düzeyi nasıldır?” olarak belirlenmiştir. Bu genel problem cümlesi doğrultusunda cevap aranan alt problemler ise şunlardır:

1. Aydın bölgesine gelen uluslararası ziyaretçilerin gastronomi davranışları bölgenin gastronomi turizmi açısından değerlendirilmesine olanak sağlamakta mıdır?

2. Aydın ili turizm paydaşlarının il gastronomik özelliklerine ilişkin görüşleri nasıldır?

3. Aydın bölgesi gastronomik özellikleri uluslararası ziyaretçiler açısından tercih sebebi olabilir mi?'dir.

Aydın ilinin gastronomik özelliklerini belirleyerek, bu özelliklerin uluslararası gastronomi katılımcıları açısından tercih ve beklentilerini karşılama düzeylerini ölçüleceği bu çalışmada karma yöntemden yararlanılmıştır. Bunun sebebi, karma yöntem araştırmaya derinlik kazandırabileceği gibi araştırmayı da zenginleştirebilir (İslamoğlu ve Alnıaçık, 2014). Dolayısıyla araştırma problemini daha iyi anlamak için bu yöntemlerden herhangi birini yalnız başına kullanmaya kıyasla daha fazla avantajlı olacaktır.

Araştırmanın ilk aşamasında bölgeye gelen turistlerin gastronomi davranışlarını ve tercihlerini belirlemek adına 15 Şubat 2016 tarihinde Kuşadası Labranda Ephesus Princess Hotel'de genel müdürlükten özel olarak alınan izinle konaklamakta olan turistlere uygulanan anket ile tamamlanmıştır. Anket Hasan Aslan tarafından 2010 yılında Konya ilinde hazırlanmış ve uygulanmış olan "Gastronomi Turizminin Turizm Eğitimi Programlarındaki Yeri ve Önemi-Bir Uygulama" isimli yüksek lisans çalışması baz alınarak hazırlanmıştır. Bu çalışmanın anket formundaki maddeler oluşturulurken Hall ve Mitchell (2005), Şanlier (2005), Akman (1998), Shenoy (2005)'in konu ile ilgili yaptığı araştırmalardan ve ilgili literatürden yararlanıldığı belirtilmektedir. Aslan'ın yapmış olduğu çalışmanın anketinde yer alan “D-Gastronomi Davranışlarını Değerlendirmeye Yönelik Sorular” bölümü demografik seyahat özelliklere göre uyarlanmıştır. Ölçekteki maddelere ilişkin katılma düzeyini ifade etmek için 5'li Likert (Kesinlikle Kat1lmiyorum "1", Kat1lmiyorum "2", Ne Kat1lyor Ne Kat1lmıyorum "3", Kat1liyorum "4" ve Kesinlikle Katılıyorum “5”) tipi dereceleme ölçeği kullanılmıştır.

Çalışmanın ikinci aşamasında, Aydın ili gastronomik özelliklerini belirlemek adına nitel boyutta katılımcılara yarı yapılandırılmış görüşme formu uygulanmıştır. Toplamda 35 katılımcı ile kendi 
ofislerinde yapılan yaklaşık 20-30 dakikalık görüşmeler gerçekleştirilmiştir. İçerik analizi tekniği ile gerçekleştirilen bu bölümde 35 adet sebze yemeği, 16 adet etli yemek, 17 adet çorba-salataaperatif, 15 adet hamur işi, 6 adet tatlı toplamda 89 adet reçete kayıt altına alınmıştır. Ancak bu çalışma esnasında reçeteleri verilen yiyeceklerin hikâyeleri olmasına rağmen, bu hikayeler katılımcılar tarafindan hatırlanamadığından aktarılamamıştır.

Araştırmanın üçüncü aşamasında ise belirlenen gastronomik özelliklerin değerlendirmesini görmek adına Mart ve Nisan tarihlerinde gerçekleştirilen uluslararası yiyecek festivallerine katılan katılımcılara Dünya Şefler Birliği'ne ait değerlendirme formu dağıtılarak Aydın gastronomik özelliklerini yansıtan menüyü değerlendirmeleri istenmiştir. Belirlenip deneyimletilen menüyü, her iki festival katılımcıları çok beğenmiştir. Puanlar, 100 puan üzerinden, Hırvatistan'da 85,6, Vietnam'da 91,3 olarak tespit edilmiştir. Çalışmanın bu bölümdeki en önemli soru olan "Gastronomi turizmi için Aydın bölgesini tercih eder misiniz?" ise Vietnam'da \% 91.3, Hırvatistan'da \% 92,2 "Evet" cevabı alarak Aydın ilinin gastronomi potansiyelinin uluslararası ziyaretçiler açısından önemli bir tercih nedeni olabileceğini göstermiştir.

\section{2 İkinci Alt Probleme İlişkin Bulgular}

Araştırmanın ikinci alt problemi "Aydın ili turizm paydaşlarının il gastronomik özelliklerine ilişkin görüşleri nasıldır?” şeklinde belirlenmişti.

Çalışmanın ikinci aşamasında bölgedeki belediyeler, turizm müdürlükleri, seyahat acentaları, ticaret odaları ve sivil toplum kuruluşları ile yapılan çalışmadan elde edilen veriler değerlendirilmiştir. Ürünlerin tarifine diğer çalışmamızda ayrıntılı yer verilmiştir (Sezgin, 2017).

1) Sizce buraya gelen turistler ne yemeli ve içmelidir?

Katılımcıların verdiği cevaplar doğrultusunda Kuşadası ve çevresini ziyaret eden turistlerin,

Yerel kahvaltı tercihleri olarak; bazlama, gözleme, çingene pilavı, tarhana çorbası, lor, taze meyvelerden yapılan reçeller, pekmez, baharatlı zeytinyağı, zeytin çeşitlerini, 
Sebze yemekleri tercihleri olarak; çeşitli otların kavrulması ile yapılan etli ve yumurtalı yemekleri, zeytinyağında yapılan sebze kızartmaları / Kırlı Kızartma (Evsilme), Zeytinyağlı salataları,

Hamur işi tercihleri olarak; bazlama, gözleme (sac böreği), tava ekmeği, Yenipazar/Bozdoğan ve Nazilli pideleri, Paşa böreği, ekmek dolması, Döndürme'yi (çeşitli otların mücver gibi hazırlanarak tavada döndürülerek pişirilmiş hali),

Pilav tercihleri olarak; Boloma, Ev Makarnası (Erişte), Pirinçli Dolmalar ve Sarmaları (Enginar, Taze Sebze Dolmaları, Ebegümeci Sarması vb),

Ana Yemek Tercihleri olarak (Et, Tavuk, Balık ve Deniz Mahsulleri); Kavurma, Keşkek, Çöp Şiş, Köfte, Kuyu Tandır, Yuvarlama, Güveç, Kabak Bastı, Yavru Kavurma, Izgara balıklar ve deniz mahsulleri, kalamar tava, karides güveç ve ahtapot tandırı,

Tatlı tercihi olarak; Kabak Tatlısı, İncir Dolması, Zerde, Pelvize, Sütlü Tatlılardan yana kullanmaları gerektiğini belirtmektedirler.

Ayrıca Kulak(l1) Çorba, Köfteli Hamur Çorbası, Tarhana, Zeytin, Zeytinyağı, Kar Helvası, İncir gibi bölgeye özgü lezzetleri tatmalarını tavsiye etmektedirler.

2) Önerdiğiniz bu yiyecek ve içecekleri nerede yemeli ve içmeliler?

Katılımcıların bölgeyi ziyaret eden turistlerin deneyim etmesini önerdiği yöresel lezzetlere önem verilmediğini ve söz konusu lezzetlerin satış amacından ziyade daha çok yerel halkın tüketmek için yaptığından tanıtılamadığını dile getirmektedirler. Nitekim söz konusu lezzetlerin birçoğu (Kızartma, Kavurma, Güveç, Bazlama, Gözleme vb.) yol üzerinde yer alan butik restoran ve küçük esnaf lokantalarında ticari amaçlı yapılmaktadır. Katılımcılar bölgeyi ziyaret eden turistlerin pideyi deneyim etmesi için Yenipazar, Bozdoğan ya da Nazilli'yi; çöp şiş için Ortakları; köfte için Çine'yi; kahvaltı için Kirazlı'yı, Değirmen Restoranı ve bazı yol üstü restoranları tercih etmeleri gerektiğini; şarap tercihlerini ise, 7 Bilgeler veya Şirince'den yana kullanmalarını tavsiye etmektedirler.

3) Önerdiğiniz bu yiyecek ve içeceklerin bir yapım hikâyesi var mı? 
Katılımcılar Kuşadası ve çevresine özgü lezzetlerin büyük çoğunluğunun fakirlik ve yokluktan ortaya çıktığı; bir kısmının ise atalarının deneyimlerinden ve bölgenin coğrafi nitelikleri ile şekillendiğini belirtilmekte, ancak yöresel lezzetlerin yapım hikâyesini hatırlamadıklarını dile getirmektedirler.

\section{3 Üçüncü Alt Probleme İlişsin Bulgular}

Araştırmanın üçüncü alt problemi "Aydın bölgesi gastronomik özellikleri uluslararası ziyaretçiler açısından tercih sebebi olabilir mi?” şeklinde belirlenmişti.

Araştırmanın ikinci aşaması sonucunda ortaya çıkartılan bilgiler 1şığında bölgenin gastronomik değerleri olarak görülebilecek yemek listesi hazırlanmıştır. Listede Sebze Yemekleri başlığ1 altında 35, Etli Yemekler başlığı altında 16, Hamur İşleri başlığı altında 15, Çorbalar - Aperatifler ve Salatalar başlığı altında 17 ve Tatlılar başlığı altında ise 6 bölgesel gastronomik lezzet olduğu tespit edilmiştir.

Belirlenen bu gastronomik lezzetler Hırvatistan ve Vietnam'da gerçekleştirilen etkinliklerde hazırlanarak katılımcılardan gastronomik bir bakış açısı getirmeleri amacı ile anket formu geliştirilerek sorulmuştur. Vietnam'da 93 ve Hırvatistan'da 77 kişi olmak üzere toplamda 170 katılımcı ile bir "Tat Anketi” gerçekleştirilmiştir.

Vietnam katılımcıların \% 25,8'i daha önce Türk mutfağını denemişken, \% 74,2'si denemediklerini belirtmiştir. Hırvatistan'da bu oranlar, \% 46,8 oranında daha önce Türk mutfağını denediğini ve \% 53,2 oranında ise denemediğini belirtmiştir. Hırvatistanlı katılımcıların Türk mutfağı hakkında daha çok bilgi sahibi oldukları görülmüştür.

İkinci soru olarak katılımcılara yemek seçiminde dikkat ettikleri en önemli özelliklerin neler olduğu sorulmuştur. Vietnamlı katılımcıların \% 40,9'u lezzete baktıklarını, \% 24,7 oranında Görselliğe önem verdiklerini, \% 19,4 oranında doyuruculuğun önemli olduğunu ve \% 15,1 oranında da fiyatın önemli bir etken olduğunu belirtmişlerdir. 
Hırvatistanlı katılımcıların \% 44,2'si lezzete baktıklarını, \% 24,7 oranında Görselliğe önem verdiklerini, \% 19,5 oranında doyuruculuğun önemli olduğunu ve \% 111,7 oranında da fiyatın önemli bir etken olduğunu belirtmişlerdir.

Ülke olarak incelendiğinde ilk sırada lezzet, ikinci sırada görsellik, üçüncü sırada doyuruculuk ve son sırada da fiyatın her iki ülke katılımcıları için önemli olduğunu göstermiştir.

Üçüncü soru olarak katılımcılara "Gastronomi turizmi için Aydın bölgesini tercih eder misiniz?" sorusu sorulmuştur. Soruya Vietnamlı katılımcıların yüzde \% 91,3'ü Hırvatistanlı katılımcıların ise \% 92.2'si evet yanıtını vermiştir.

\section{Sonuç ve Değerlendirme}

Aydın ilinin gastronomik özelliklerini belirleyerek bu özelliklerin uluslararası gastronomi katılımcılarının tercih ve beklentilerini karşılama düzeylerini ölçmeyi amaçlayan bu çalışmanın ilk aşamasında bölgeyi tercih eden uluslararası ziyaretçilerin gastronomi davranışları ve tercihleri anlaşılmaya çalışılmıştır. Çalışmanın ikinci aşamasında ise içerik analizi uygulaması ile Aydın ilinin gastronomik özellikleri belirlenmiştir. Belirlenen bu özelliklerden oluşturulan özel tadım menüsü ile çalışmanın son aşaması Vietnam ve Hırvatistan'daki uluslararası yiyecek festivallerine katılanlar üzerinde tamamlanmıştır.

Araştırmanın anakütle ve örneklemi 3 farklı şekilde tespit edilmiştir. İlk bölüm için anakütle, Aydın iline gelen turistler olarak belirlenmiş, çalışma tarihi Şubat ayı olmasından dolayı o tarihlerde Kuşadası bölgesinde açık bulunan Labranda Ephesus Princess Otel misafirleri örnekleme alınmıştır. İkinci bölüm için, anakütle Aydın ili turizm paydaşları olarak belirlenmiş, yarı yapılandırılmış sorular paydaşların belirlenen katılımcılar ile gerçekleştirilmiştir. Üçüncü bölümde ise, anakütle Mart ve Nisan tarihlerinde gerçekleştirilen uluslararası yiyecek festivallerine katılan katılımcılar olarak belirlenmiştir. Bu aşamada uygulanan Dünya Şefler Birliği'ne ait değerlendirme formu, araştırmacının davet edildiği ise 14-20 Mart 2016 Hoi An Food Festival Vietnam (93 kişi) ve 7-10 Nisan 2017 Biser Mora Hırvatistan (77 kişi) katılımcılarına uygulanmıştır. Anakütlenin kaç kişi olduğu bilinmediğinden, kolayda örnekleme tekniği kullanılarak, menüyü deneyenlere uygulanmıştır. 
Araştırmanın ilk bölümünü oluşturan, bölgeyi tercih eden uluslararası ziyaretçilere uygulanan anket sonucunda iki ayrı bölümde toplam 5 ayrı faktör tespit edilmiştir. Bu bölümlerden "Gastronomi Davranışları" ölçeği faktör analizi sonucunda katılımcıların ifadelerinin 2 temel faktör altında toplandığı görülmüştür. "Farklı yörelerin beslenme kültürünü bilmek isterim", "Yeni tatlara güvenmem", "Alı̧̧ı olmadığım tatları denemek isterim", "Dışarıda yemek yediğimde farklı tatları denerim" ve "Dışarıda yemek yiyeceğim zaman farklı yörelerin mutfakların tercih ederim" ifadelerinin "Gastronomi Deneyimi I" alt faktörü olarak, "Yemek festivallerine katılırım", Bir restorana gittiğimde şefin özel yemeğini sipariş ederim", "Yemek yaparken yeni yemekleri yapmayı denerim", "Yemek mönüsünde ismini ilk defa gördüğüm yiyecekleri merak ederim", "Dışarıda yemek yiyeceğim zaman, alışık olduğum yemekleri tercih ederim" ve "Sürekli yeni yiyecekler denemek isterim" ifadelerinin "Gastronomi Deneyimi II" alt faktörü olarak isimlendirilmesine karar verilmiştir.

Bir bölgenin yemek kültürü, o bölgenin tercih edilmesi ve o bölgeye gelen ziyaretçilerin deneyimleri için önemlidir. Çünkü bölge yemekleri, o bölgenin iklimi, manzarası vb. önemli çekicilik özellikleri arasında bulunmaktadır. Değişik yemekleri deneyimleme, seyahat amacının temel motivasyonu olabileceği gibi toplam deneyimin alt amacı da olabilmektedir (McKercher, Okumuş ve Okumuş, 2008). Turistlerin günlük hayatlarında dikkatlerini çekmeyen bazı yiyecekler, deneyimleri sonucunda sembolik anlamlar yükledikleri ve tatillerinin bitiminde de bölgeyi hatırlamalarını sağlayacak etkiler bırakabilir. Dolayısıyla yemek tüketimi sadece kültür paylaşımı, macera, keşif ya da keyif için olsa da, turistlerin yerel gelenekleri gıdalar ile öğrenmesini sağlayan olumlu bir gastronomi deneyimine dönüşmektedir (Silkes, 2007).

Yeme-içme deneyimleri beş duyu organı ile algılanan, bireysel, katılımcı ve arzuları tatmin eden, tatil süresince yaşanan diğer deneyimlerden daha çok akılda kalan ve uzun süre unutulmayan deneyimlerdir. Dolayısıyla Türkiye'ye gelen turistlerin gastronomi deneyimleri özelde Aydın genelde ise Türk Mutfağı ve gastronomi turizmi için büyük önem arz etmektedir.

"Gastronomi Tercihleri" ölçeği faktör analizi sonucunda ise katılımcıların ifadelerinin 3 faktör altında toplandığı görüşmüştür. " ...yol kenarında satılan yiyecekleri tercih ederim.", "...yerel yemekleri tercih ederim.", "...yerel lokantaları tercih ederim.", "...hazırlanışını görebileceğim yiyecekleri tercih ederim.", "...dünyaca ünlü lokanta zincirlerini tercih ederim.", "...yöresel 
sunulan yemekleri ve yöreyi yansıtan yiyecekleri tercih ederim.", ifadelerinin "Tercih Faktörü" alt faktörü olarak, "...hazır yiyecekler tüketirim. (Bisküvi, konserve vb.)", "...yemek yerken inanç sistemime uygun yerler seçerim.", "...yöresel yiyecek hazırlama araç gereçlerini satın alırım.", ifadelerinin "Satın Alma Faktörü I" alt faktörü olarak, "...yörenin özel yiyeceklerinden satın alırım.", "...yöresel yemek kitapları satın alırım." ifadelerinin ise "Satın Alma II" alt faktörü olarak isimlendirilmesine karar verilmiştir.

Son y1llarda geleneksel ve kültürel değerler önem kazanmış, turistlerin destinasyon tercihlerinde özellikle yerel değerlere sahip çıkan bölgeler daha çok tercih edilir olmuştur (Sünnetçioğlu vd. 2012). Göller (2016) tarafindan yapılan tez çalışmasına göre gastronomi turizminin gelişmesi için yerel ürünleri ve yöresel yemekleri dikkate almak pazarlama faaliyetleri açısından büyük önem taşımaktadır.

Yerel ürünler, piyasada ayırt edici sunumu ve çekiciliği ile ekonomisini tarımsal ürünlerden sağlayan ve gelişmekte olan bazı ülkelerin ihracat hacimlerinin önemli bir yüzdesini karşılamaktadır. Avrupa Birliğinde 2003 yılında yapılan çalışmalarda; Fransız yöresel peynirlerinin normalinden $2 €$ daha fazla fiyata alıcı bulduğu, İtalyan Toscano yağlarının tescilinden itibaren \% 20 daha fazla fiyata satıldığı, ihraç edilen Fransız şaraplarının \% 85'inin coğrafi işaret taşıdığı görülmektedir (Birinci, 2008: 85-86).

Araştırmanın ikinci aşamasında 35 katılımcı ile kendi ofislerinde yapılan yaklaşık 20-30 dakikalık görüşmeler esnasında, kendilerine yöneltilen sorular sonucunda Aydın ilinin gastronomik özellikleri tespit edilmeye çalışmıştır. İçerik analizi tekniği ile gerçekleştirilen bu bölümde 35 adet sebze yemeği, 16 adet etli yemek, 17 adet çorba-salata-aperatif, 15 adet hamur işi, 6 adet tatlı toplamda 89 adet reçete kayıt altına alınmıştır. Ancak bu çalışma esnasında reçeteleri verilen yiyeceklerin hikayeleri olmasına rağmen, bu hikayeler katılımcılar tarafindan hatırlanamadığından aktarılamamıştır.

Çalı̧̧manın son aşamasında Vietnam ve Hırvatistan'da düzenlenen uluslararası yiyecek festivallerinde uygulanan değerlendirme ölçeğine göre Hırvatistan'da etkinliğe katılanların Türk Mutfağı hakkında daha fazla bilgiye sahip oldukları görülmüştür. Bunun en önemli nedenlerinden biri Hırvatistan'ın Vietnam'a kıyasla Türkiye'ye daha yakın olmasıdır. Ayrıca iki ülkede de festivale katılanlar kendileri için yemek seçiminde önceliğin lezzet olduğunu belirtmişlerdir. 
Lezzeti sırasıyla görsellik, doyuruculuk ve fiyat takip etmektedir. Belirlenip deneyimletilen menüyü, her iki festival katılımcıları çok beğenmiştir. Puanlar, 100 puan üzerinden, Hırvatistan'da 85,6, Vietnam'da 91,3 olarak tespit edilmiştir. Çalışmanın bu bölümdeki en önemli soru olan "Gastronomi turizmi için Aydın bölgesini tercih eder misiniz?" ise Vietnam'da \% 91.3, Hırvatistan'da \% 92,2 "Evet" cevabı alarak Aydın ilinin gastronomi potansiyelinin uluslararası ziyaretçiler açısından önemli bir tercih nedeni olabileceğini göstermiştir.

Coğrafik ve ekonomik gelişme potansiyeline sahip bölgeler gastronomi turizminin gelişimi için çok önemlidir. Destinasyon için seyahat acenteleri, kamu kurum ve kuruluşları, restoranlar ve otel işletmeleri arasında işbirlikleri geliştirilmeli, uzun dönem stratejik planlar düşünülmeli ve bu planlar doğrultusunda eğitim faaliyetleri düzenlenerek bilgilendirme yapılmalıdır. Böylece destinasyonlarda kalite artışı ve devamlılık sağlanabilir (Boyne ve Hall, 2003; Ontario, 2008; Harrington\&Ottenbacher, 2010).

Araştırmadan elde edilen sonuçlar göz önüne alınarak gerçekleştirilen öneriler aşağıda sıralanmıştır;

1. Aydın mutfağının gastronomi turizmi içindeki yeri konusunda farkındalık yaratmak ve turizm paydaşlarını bilinçlendirmek gerekmektedir. Bunun için Aydın ili gastronomik özellikleri kitaplaştırılabilir. Otel ve restoran işletmeleri bu konuda bilgilendirilerek menülerinde Aydın mutfağı reçetelerine yer vermeleri teşvik edilebilir.

2. Aydın'da gastronomi turizminin geliştirilmesi için kitle iletişim araçları, dergi ve broşürler, internet ve seyahat acenteleri yoluyla Aydın mutfak kültürünü tanıtmaya yönelik çalışmalar hazırlanabilir ve bu çalışmalar teşvik edilebilir.

3. Aydın ilinin yemek kültürünü ulusal ve uluslararası platformlarda duyurmak ve bu alanda Aydın ilini bir marka haline getirebilmek için yerel yiyecek üreticileri ve bu ürünleri satanlar ile yerel yönetimin birlikte çalışması gerekmektedir.

4. Tur operatörleri ve seyahat acentaları Aydın mutfağını içermek üzere Türkiye'nin çeşitli yerlerini kapsayacak gastronomi turizmine kapsamlı paket turlar düzenleyebilirler. 
5. Aydın ili gastronomi turizminin geliştirilmesine yönelik eylem planları ve stratejiler hazırlayacak birimler kurulabilir.

6. Türkiye'de düzenlenen yerel gastronomi etkinliklerine, festival ve şenliklere yerli ve yabancı turistlerin katılımının arttırılması ve bu etkinliklerde yerel yemeklerin tanıtılması için çaba harcanabilir.

7. Bu çalışmada elde edilen bulgular, farklı il kültürlerinin dâhil edildiği karşılaştırmalı çalışmalar için yol gösterici olabilir.

\section{Kaynakça}

Akgöl, Y. (2012). Gastronomi Turizmi Ve Türkiye'yi Ziyaret Eden Yabancı Turistlerin Gastronomi Deneyimlerinin Değerlendirilmesi, Yayımlanmış Yüksek Lisans Tezi, Mersin Üniversitesi Sosyal Bilimler Enstitüsü, Mersin.

Altınel, H. (2009). Gastronomide Menü Yönetimi. Yayımlanmamış Yüksek Lisans Tezi, İstanbul Üniversitesi Sosyal Bilimler Enstitüsü, İstanbul.

Aslan, H.(2010). Gastronomi Turizminin Turizm Eğitimi Programlarındaki Yeri Ve Önemi: Bir Uygulama, Yayımlanmamış Yüksek Lisans Tezi, Selçuk Üniversitesi Sosyal Bilimler Enstitüsü, Konya.

Belge, M. (2008). Tarih Boyunca Yemek Kültürü̈, İletişim Yayınc1lık, İstanbul.

Boniface, P. (2003). Tastingtourism: Traveling For Foodanddrink. Ashgate Publishing Limited. 
Ciğerim, N. (2001), “Batı Ve Türk Mutfağı’nın Gelişimi, Etkileşimi Ve Yiyecek-İçecek Hizmetlerinde Türk Mutfağının Yerine Bir Bakış”, Türk Mutfak Kültürü Üzerine Araştırmalar, Türk Halk Kültürünü Araştırma Ve Tanıtma Vakfı Yayınları Yayın No: 28, 49-61.

Cook, R. A., Yale, L. J., Marqua, J. J. (1999). Tourism: The Business Of Travel. Prentice Hall (Uppersaddleriver, N.J.)

Çetin, İ. (2001). Turistik Ürün Çeşitlendirilmesinde Eko-Turizmin Yapısal Analizi Ve Türkiye'de Geliştirme Stratejileri (Örnek Bir Uygulama), Yayımlanmamış Yüksek Lisans Tezi, Balıkesir Üniversitesi Sosyal Bilimler Enstitüsü, Balıkesir.

Dilsiz, B. (2010). Türkiye'de Gastronomi Ve Turizm (İstanbul Örneği), Yayımlanmamış Yüksek Lisans Tezi, İstanbul Üniversitesi Sosyal Bilimler Enstitüsü, İstanbul.

Gillespie, C., Cousins, J. A. (2001). European Gastronomyinto The 21 st Century. ButterworthHeinemann.

Göller, V. (2016). Yerel Yemek Tüketiminin Turist Motivasyonuna Etkisi, Yayımlanmamış Yüksek Lisans Tezi, Muğla Sttkı Koçman Üniversitesi, Sosyal Bilimler Enstitüsü, Muğla.

Hall, C. M.,Mitchell, R., Sharples, L. (2003), Consuming places: The Role Of Food, Wine and tourism In Regional development.In C. M. Hall, L. Sharples, R. Mitchell,N. Macionis, \& B. Cambourne (Eds.), Food tourism around The World, (25-59). Oxford, Uk: Elsevier butter worthHeinemann.

Hall, M., Sharples, L. (2003). The Consumption Of Experiencesor The Experience Ofconsumption? An Introduction To The Tourism Of Taste. Hall, M., Sharples, L., Mitchell, R., Macionis, N. Ve Cambourne, B., (Ed.), Food tourism around The World, (1-25). London: Butter worth heinemann.

Harrington, R. J., And Ottenbacher, M. C. (2010), Culinarytourism - A Case Study Of The Gastronomiccapital, Journal Of Culinary science \& Technology, 8, 14-32.

Hatipoğlu, A., (2010). İnançların Gastronomi Üzerine Etkileri: Bodrum'daki Beş Yıldızlı Otellerin Mutfak Yöneticilerinin Görüşlerinin Belirlenmesine Yönelik Bir Araştırma. Yayımlanmış Yüksek Lisans Tezi. Sakarya Üniversitesi Sosyal Bilimler Enstitüsü, Sakarya. 
Hatipoğlu, A., Batman, O., Sarışık, M. (2009). Gastronomi Ve Din, 3. Ulusal Gastronomi Sempozyuтu Bildirisi, Alanya, 17-18 Nisan

Hjalager, A., M., Corigliano, M., A. (2000). Food For Tourists determinants Of An İmage. International Journal Of Tourism Research, 2, 281-293.

İslamoğlu, A. H., Alnıaçı, Ü. (2014). Sosyal Bilimlerde Araştırma Yöntemleri. İstanbul:Beta Yayın Dağıtım.

Kastenholz, E, Davis D, Paul G. (1999). Segmenting Tourism İn Rural Areas: The Case Of North and Central Portugal. Journal Of Travel Research, 37, 353-363.

Kemer, K. A. (2011). Otellerde Çalışan Mutfak Personelinin Ve Aşçılık Alanında Yüksek Öğrenim Gören Öğrencilerin Moleküler Gastronomi Konusundaki Bilgi Ve Görüşleri, Yayımlanmamış Yüksek Lisans Tezi, Gazi Üniversitesi Eğitim Bilimleri Enstitüsü, Ankara.

Küçükaltan, G. (2009). Küreselleşme Sürecinde Gastronomide Yöresel Tatların Turistlerin Destinasyon Tercihlerine Ve Ülke Ekonomilerine Etkileri, 3.Ulusal Gastronomi Sempozyumu Bildirisi, Alanya, 17-18 Nisan

Long, L. (2003). Culinary tourism. Lexington. Abd: The University Press Of Kentucky.

Mckercher, B., Okumuş, F., Okumuş, B. (2008). Food tourism As A Viable Market Segment: İt'sall How You cook The Numbers. Journal Of Travel \&Tourism Marketing, 25(2), 137- 148.

Sezgin, E. K. (2017). Potansiyel Ve Efektif Ziyaretçilerin Gastronomi Davranışları: Aydın İli Mutfak Kültürü Örneği, Yayınlanmamış Doktora Tezi, Adnan Menderes Üniversitesi, Sosyal Bilimler Enstitüsü, Aydın.

Shenoy, S. (2005). Food Tourism And The Culinary Tourist, A Thesis Presented To The Graduate School Of Clemson University, South Carolina.

Silkes, C. A. K. (2007). Food And Food Related Festivals In Rural Destination Branding, Purdue University, Indiana.

Sünnetçioğlu, S., Can, A., Durlu-Özkaya, F. (2012). Yavaş Turizmde Coğrafi İşaretlemenin Önemi, 13. Ulusal Turizm Kongresi, Antalya, 953-962. 
Uluslararası Ziyaretçilerin Gastronomi Davranışları ve Beklentileri: Aydın İli Örneği

Ülker, İ.(1998). Yıl Boyu Turizm Yapılması Ve Turizmin Çeşitlendirilmesinde Dă̆ Ve Kıyı Turizmi İle Termal Turizm Yeri, Ankara, T.C. Turizm Bakanlığı, 1. Turizm Şurası.

Wolf, E. (2006). Culinarytourism The Hiddenharvest, Kendall/Hunt Publishing Company, AbdLowa

Yüncü, H. R. (2010). Sürdürülebilir Turizm Açısından Gastronomi Turizmi Ve Perşembe Yaylası, Aybastı-Kabataş Kurultayı 11, 19-26, Ankara. 